Iaremenko, Maksym. "Akademiky" i Akademiia.

Sotsialna istoriia osvity i osvichenostiv Ukraini XVIII st. Kharkiv: Akta, 2014

Reviewed by: Kateryna Dysa

Source: Kyiv-Mohyla Humanities Journal 2 (2015): 155-157

Published by: National University of Kyiv-Mohyla Academy

http://kmhj.ukma.edu.ua/ 
Максим Яременко

“АКАДЕМІКИ” ТА АКАДЕМІЯ

СОЦАЛЬНА

ICTOРІЯ

OCBITИ

Й ОСВІЧЕНОСТІ

В УКРӒ̈Н

$\mathrm{XVIII}$ ст.

\section{Maksym Iaremenko}

\section{"Academicians" and the Academy: A Social History of Education and Literacy in 18 th-century Ukraine}

\author{
["Akademiky" i Akademiia. Sotsialna istoriia osvity \\ i osvichenosti $v$ Ukraini XVIII st.]. \\ Kharkiv: Akta, 2014. 534 pp. In Ukrainian. \\ ISBN: 978-966-8917-65-3
}

\section{Reviewed by Kateryna Dysa}

Thehistory of education is a well-established trend in bothWestern and Ukrainian historiography. From the 196os on historians wrote hundreds of monographs about individual and institutional educational practices. Since the 19th century, many historians have turned their attention to the history of the Kyiv-Mohyla Academy. The main problem with these studies, as Maksym Iaremenko points out in his new book, is their uncritical use of the 19th-century researchers' statements, for instance, concerning students' social backgrounds and the geography of their origins, as well as a lack of wider historical context (pp. 18-27). So, the author tries to look at the history of the Kyiv-Mohyla Academy with quite a fresh eye, putting his subject into the context of the history of early modern education.

Maksym Iaremenko is an experienced researcher of the 18th-century history of the KyivMohyla Academy and the history of education in Ukraine in general. For many years he acted as Head of the Centre for the Study of the Heritage of the Kyiv-Mohyla Academy, has been an editor of the journal Kyivska Akademia, and published dozens of articles on the history of education in Ukraine.

The book has, in a way, a dialogical format: the author argues with historians who have previously studied the Kyiv-Mohyla Academy, scrutinizing some of their claims (for instance about the social origins of the students and literacy as a common phenomenon in the Hetmanate) and deconstructing them.

The focus of the monograph is on the students of the Kyiv-Mohyla Academy of the 18th century ("academicians" from the title), which is why Maksym Iaremenko starts his book with a prosopographic chapter about the boys and young men studying at the Academy, using detailed lists of the students for the years $1737-1738$ as a starting point. The most exciting part of this chapter is a deconstruction of the myth about huge numbers of students (about 2,00o) at the Kyiv-Mohyla Academy in the early 18th century (pp. 90-123). This statement was first made by foreigners who visited Kyiv in the 18th century and was later repeated by early 
researchers of the history of the Academy and from then on drifted from one study to another without any critical reflections. Iaremeko demonstrates that methods of such calculation were very imperfect. Elegantly using sources and testimonies from broader contexts, he shows that it was impossible to accommodate this number of students, neither in terms of the physical space available, nor in terms of material provision.

In the next five chapters, the author one by one explores social groups from which the Academy's students came, moving from the most privileged (Cossack foremen [starshyna] and szlachta) down to the least privileged (pospolyti, common town and village dwellers), and finishing with the most numerous group, the clergy.

All of these chapters have roughly similar structure. Each of them starts with rather monotonous calculations and basic data about the students: number of boys coming from this or that social group, their ages, which classes they attended, their progress in studies. This information may seem a bit tedious and dull, however it adds necessary background for further analysis. Moreover, all the information mentioned in these statistical parts is neatly organised into tables (the most cumbersome tables are removed from the main text and can be found in handy appendixes). These statistical parts of the chapters are followed by more exciting narrative parts, in which Maksym Iaremenko attempts to answer various challenging questions, which troubled many researchers before him.

While discussing students from Cossack families, the author faces the problem of personal identification in the early modern period, when people did not yet have family names. So Maksym Iaremenko skilfully ascertains the identity of Cossack children at the Academy, using additional sources, such as census data. Another question the author strives to answer in this chapter: what motivated Cossack children to get an education? In the case of Cossack foremen [starshyna] who composed the new imperial bureaucracy, education was an important condition to ensure aggrandizement. However, as Iaremenko demonstrates, the curriculum of the Kyiv-Mohyla Academy was hopelessly outdated for 18th century challenges. New elites demanded secular disciplines, such as the French and German languages, history and geography, which were extremely slow to be introduced into the Academy's actual curriculum (pp. 208-21). That is why the Kyiv-Mohyla Academy was not an ideal choice for this social group, who needed a modern education. Turning his attention to common Cossacks, Iaremenko concludes that up till the mid-18th century Cossacks did not show any respect for education and literacy in general (pp. 222-25).

The key question posed in the next chapter: what attracted students (chiefly of szlakhta origin) from the Polish-Lithuanian Commonwealth to the Kyiv-Mohyla Academy? The author discards claims about the outstanding popularity of this institution in the region. However, he accepts the possibility that young men from Greek-Catholic szlakhta families might have felt more comfortable in the Orthodox school of the Hetmanate than in Jesuit schools of the PolishLithuanian Commonwealth. At the same time, he argues that in fact, connections between the two neighbouring territories of the Hetmanate and Polish-Lithuanian Commonwealth were quite tight and were not limited exclusively to education (pp. 252-59).

The shortest chapter focuses on students from cities, who were mainly from wealthy families and almost half of them were from Kyiv. Having studied a variety of sources from early modern town magistrates, Maksym Iaremenko concludes that even the education of magistrate 
members (who can be related as a relatively privileged class and needed education for their profession) was rather poor.

In my opinion, the chapter about the education and literacy of the common people [pospolyti] is the book's central chapter. In this chapter, the author demystifies the myth about widespread literacy among common people of the early modern Hetmanate. The myth about mass literacy of the people rests upon information about a large quantity of elementary schools in the Hetmanate, misinterpretation of the term shkolnik [schoolboy], and a wrong idea about the cost of elementary education (researchers generally presumed that it was for free). Maksym Iaremenko demonstrates that those buildings which used to be counted in inventories as "schools" could be in fact houses to accommodate local diaks [clerks] (p. 313). In a similar manner shkolniki [schoolboys] were not pupils but grown up men (usually paupers) living in schools (pp. 324-31). It is also worth remembering, the author argues, that elementary education was not for free and that is why it was not accessible to all people. Finally, numerous testimonies of 18th-century contemporaries also prove that the level of literacy of the common people of the Hetmanate was extremely low, and that educated peasants were considered to be a rarity.

The final chapter is dedicated to students of clerical origin, the most numerous social group represented at the Kyiv-Mohyla Academy. The author uses this topic as an occasion to discuss education as a factor of discipline implementation and concludes that in the case of clerical education, it was not very effective.

At the end I would like to add a couple of remarks. Though the title of the book announces that it will tell us all about "the Academy and academicians," in fact it is focused exclusively on the students, and in this case professors are excluded from "academicians." I would also like to assume that the book is directed at prepared readers who have preliminary knowledge about the history of early modern education with its nuances. It would have been handy to provide some basic information about the structure of education and study curriculum in "Latin schools" for readers who are not experts in the area.

To conclude, Maksym Iaremenko's work is a particularly valuable study adding new dimensions to the discussions on the history of early modern education in Ukraine. The author is far from praising the contribution of the Kyiv-Mohyla Academy and its alumni for the cultural development of Ukraine, instead he provides his reader with a realistic depiction of the state of affairs of 18th-century education. 